\title{
Postponing Births - Comparing Reasons Among Women in St Petersburg, Estonia and Finland
}

REGUSHEVSKAYA ELENA, National Institute for Health and Welfare, Helsinki HEMMINKI, ELINA, National Institute for Health and Welfare, Helsinki KLEMETTI, REIJA, National Institute for Health and Welfare, Helsinki ROTKIRCH, ANNA, Population Research Institute, Väestöliitto KARRO, HELLE, University of Tartu, Estonia HAAVIO-MANNILA, ELINA, Department of Sociology, University of Helsinki MIETTINEN, ANNELI, Population Research Institute, Väestöliitto

\begin{abstract}
We compared the reasons for postponing first birth in the three neighbouring areas of St Petersburg (Russia), Estonia and Finland. Data from three population-based surveys among women aged 18-44 years in St Petersburg (response rate 67\%); Estonia (54\%) and Finland (63\%) in the early 2000s were used and analysed with logistic regressions. Childbearing intentions and reasons for postponing parenthood differed between both study areas and age groups. The proportion of women aged 35-44 still planning to have children was highest in Estonia. In the two post-Soviet areas, job insecurity increased postponement intentions among women aged 18-34 years. Enrolment in education was an important reason for postponement among women below 35 years in Estonia and aged 25-34 years in St Petersburg. In Finland, poor economic situation in the youngest age group and desire to advance a career among all women were important reasons to postpone birth. The importance of prolonged education and job insecurity for the timing of births in St Petersburg and Estonia suggests that governments should improve family policy measures to encourage childbearing among the young. In Finland policies to support the reconciliation of family and career and to increase permanent employment could promote parenthood among well-educated women,
\end{abstract}

Key words: Childbearing intentions, birth postponement, Estonia, Finland, Russia

\section{Introduction}

The decline in fertility to below replacement levels combined with higher ages of first birth began in Western and Northern Europe in the late 1960s (HFA-DB 2010; Frejka and Sardon 2006; Frejka et al. 2008; Sobotka 2008) with fertility levels stabilizing during the 1990s. In Central and Eastern Europe, the decline in fertility started later, in the 1990s, following a long period characterized by comparatively early first birth and postponement of second and higher order births (Frejka et al. 2008; Perelli-Harris 
2005; Sobotka 2004). In contemporary western European countries, women give birth to their first child at ages 28-29 on average, whereas in many post-communist central-eastern European countries, in which the postponement of first births started later, the age at first birth is still lower, or around 24-25 years (Sobotka 2004, 2008).

Most young EU citizens want to have children (Goldstein, Lutz and Testa 2003; Testa 2007,2011 ). Typical reasons for postponing birth relate to the wish to complete education before having children as well as acquiring a stable job and income, and having good housing conditions (Cooke, Mills and Lavender 2010; Heck et al. 1997; Rønsen 2004; Sobotka 2004). At the same time, there is a growing acceptance of childlessness as a life choice (Tanturri and Mencarini 2008; Sobotka 2009). Studies among women who have had abortions likewise suggest that social and financial concerns are important reasons for postponing the birth of the first child (Rasch, Knudsen and Wielandt 2001; Larsson et al. 2003).

In contrast, the literature on postponing first births from Eastern Europe, Russia in particular, is notably scarce, and describes mainly fertility trends and macro-level political and socioeconomic conditions relating to it, dealing with the transformation of reproductive behaviour patterns towards older ages of childbearing (e.g. Zakharov 2008). Many of the post-Soviet countries have undergone major social and political changes, which are likely to affect young adults' fertility behaviour. The current spread of low and lowest-low fertility in these countries is partly a consequence of delayed childbearing, which may also, however, contribute to lower completed fertility in the future. It is generally believed that fertility levels will rise once socioeconomic and institutional constraints will be reduced. However, we know very little of micro-level determinants of postponement of parenthood, and the reasons behind young women's childbearing plans.

This article aims to improve the understanding of factors related to delayed childbearing among young adults in Eastern European countries by comparing fertility intentions and the reasons for postponing first birth in three culturally similar neighbouring areas, though with otherwise very different sociopolitical (post-Soviet and Nordic) developments: St Petersburg, Estonia and Finland. Our main interest lies in the self-rated motivations for postponement of childbearing among young women in these three areas, with a specific focus on motivations related to the socio-economic situations of the women. The data comes from national surveys conducted in early 2000s and allowing us to investigate factors related to postponement of childbearing during a period when profound societal changes took place in the two post-Soviet areas. 


\section{Background and national contexts}

Although Estonia and Russia share a long sociopolitical history and both are former Soviet states, there are important differences between these countries in regard to recent fertility developments. Both Russia and Estonia experienced a deep fertility decline in the early 1990s. In Estonia, the total fertility rate started to increase already by the end of the 1990s, while in Russia, the increase has been more modest and took place later (HFA-DB 2010; Sobotka 2004; Zakharov 2008). In Estonia, the mean age at first birth started to increase during the first half of the 1990s. Russia experienced a slight decline in the age at first birth in the beginning of the 1990s but around 1995 this trend reversed (Sobotka 2004). In Finland, the total fertility rate has been rather stable at 1.8, although postponement of parenthood has been a prominent trend during the last decades. Since the late 1990s, however, the mean age at first birth has been increasing only marginally (Statistics Finland 2008).

\section{Russia and St Petersburg}

In the 1990s, young people in Russia experienced significant social changes and rapid socioeconomic transformation placing them at risk of social, educational and economic challenges. The post-Soviet changes in economic development created a decline in the economic activity of young people but at the same time increased their enrollment in further education. As an example, in 1998 in Russia the unemployment rate of young people was $27 \%$ (UNICEF 2000).

The total fertility rate (TFR) decreased to very low levels by the end of the 1990s. In the early 2000s there was a slight increase in TFR, mostly as a result of the age cohort of women born in the 1980s entering their fertile period in the 2000s (Zakharov 2002; Chistyakova 2004). During the late 1990s and early 2000s, a complex transformation took place that included new attitudes, beliefs and perceptions towards marriage, childbearing and the modern family (Sobotka 2004; Zakharov 2008; Rotkirch and Kesseli 2012). In spite of historically prevailing norms towards childbearing at a young age and having a big family, young contemporary Russian women have decided on later childbearing and having fewer children (Zakharov 2008).

During the socialist era, the involvement of women in the labour market was high. All employed women who delivered a child had a right to parental benefits including parental leave and child allowance. In addition, state policies supported families with children by providing daycare for preschool children and programs for school children. Since the 1990 s to the beginning of the 2000s there were no major initiatives or dramatic changes in the social provisions for young people. Although in the beginning of the 2000s there were modest childbirth allowances and allowances for children aged 1.5 years to 6 years (Elizarov 2002), many young families were at risk of poverty after delivering a first child (Ovtcharova 2005). Later the main family policies were geared to reducing the list of social indications for induced abortions 
(Decree No. 485 2003) and the introduction of the maternal capital (Zakharov 2008; Rotkirch, Temkina and Zdravomyslova 2007). Despite the slight increase in the total fertility rate in early 2000s up to 1.29 in 2005, fertility in Russia remains below the replacement level and on a clearly lower level than in Estonia and Finland (HFA-DB 2010) and in other parts of Europe (Sobotka 2004). In St Petersburg, which is one of the biggest metropolitan areas in Russia, the TFR was 1.13 in 2002 around the time of this study (St Petersburg Public Health Committee 2010).

\section{Estonia}

Since gaining its independence in 1991 the situation of young people in Estonia has been slightly better than in Russia, but also characterized by a high unemployment rate and high enrolment in secondary and tertiary education (UNICEF 2000). Estonia experienced a steep fertility decline in the 1990s with the TFR decreasing from 1.7 in 1992 to 1.27 in 1998. Age at first birth started increasing at the beginning of the 1990s, being 22.7 years in 1992 and 24.8 years in 2004, which was later than in western or central European countries, although earlier than in Russia (Sobotka 2004; Estonian Birth Medical Registry 2009).

Since the beginning of the 1990s, cohabiting has significantly increased and marriage decreased in Estonia. The proportion of cohabiting mothers among all mothers was 27\% in 1992, and 49\% in 2004 (Estonian Medical Birth Registry 2009).

Many efforts to reduce the abortion rate and improve the family planning situation in Estonia were made in the middle of 1990s, with improvements in contraceptive counseling and school-based sex education (Karro 1997). The situation in family policies was perceived as a conflict between expectations based on a family-friendly policy environment and the actual policy, which remained basically unchanged from the 1990s to the beginning of the 2000s (Estonian human development report 2002, 2008). At the beginning of 2000s the Estonian government addressed the problem of low fertility by extending the payment of parental benefits and promoting and sponsoring an in vitro fertilization (IVF) program (Sotsiaalministeerium 2010.). The new Parental Benefit Act entered into force in 2004 and aimed to compensate for income not received by stay-athome parents. Parental benefits (parental leave) were made available to both parents, as fathers could use parental leave without losing previous income. Both parents could return to their full-time jobs. In 2004 the Estonian Health Insurance Fund started to compensate women aged under 35 for IVF treatment. These changes together with the recovery of the levels of employment and the emergence of new career possibilities may contributed to the increase in fertility rates in 2004 and 2005, with a total fertility rate of 1.5 (HFA-DB 2010; National Institute for Health Development 2012). 


\section{Finland}

In Finland, fertility was at its lowest in the beginning of the 1970s (TFR at 1.5) after which it started to increase. Since the early 1990s the total fertility rate has fluctuated around 1.8 (HFA-DB 2010). However, postponement of childbearing has been a prominent trend, and currently the mean age at first birth is 28 years (Statistics Finland 2012). Compared to Russia and Estonia, Finland is an affluent welfare society, and since the 1970s, it has had a comprehensive family policy with relatively generous benefits and services for families with children. Universal social security benefits such as unemployment benefits, student benefits, sickness benefits, as well as housing and basic income benefits provide economic security, even if the level of some benefits is relatively low (Forssén 2000). Since 1990, an additional family provision, home care allowance has been available to those parents (usually mothers) who want to stay at home to take care of a below three-year-old child. Thus, for example, young parents, who are studying or unemployed are entitled to have some modest level of income. Extensive and relatively inexpensive childcare services further support the reconciliation of work or studies and family, and are likely to influence couples' childbearing decisions.

Finnish women's labour force participation rate is on a higher level than in many other western European countries, resembling that of its eastern neighbours. During the 1990s and early 2000s the country experienced economic down- and upturns, accompanied with increasing enrollment in higher education particularly among women, and considerably high unemployment level of the young, being around $20 \%$ in early the 2000s (Statistics Finland 2008).

\section{Data and methods}

Data from three population-based surveys in the early 2000s were used. In St Petersburg a survey of women aged 18-44 was conducted in 2003-2004 using a random sample of 2501 women, of whom 1718 women were reached and 1147 chose to participate (response rate $=67 \%$ ). The survey was approved by the Ethical Committee of the St Petersburg Medical Academy for Postgraduate Studies. A more detailed description of the survey has been published previously (Kesseli et al. 2005; Regushevskaya et al. 2008; Regushevskaya et al. 2009).

In Estonia, an anonymous postal survey was conducted in 2004-2005. A stratified random sample with equal numbers of women in the age groups 16-25, 26-35 and 36-44 years was taken from the national population register (Part et al. 2007). The total sample size was 5190 women (response rate $=54 \%$ ). The survey was approved by the Ethics Review Committee on Human Research at the University of Tartu, Estonia. A more detailed description of the survey has been reported earlier (Part et al. 2007; Laanpere et al. 2012).

In Finland, a postal survey was conducted among 7000 men and women, aged 18-69 years in 2002. The sample was a simple random sample drawn from the population 
register. The response rate among women was $63 \%$ (Paajanen 2005). The survey was not handled by a research ethics committee, as anonymous sociological surveys in Finland are not customarily reviewed by ethics committees.

The St Petersburg and Estonian surveys covered various aspects of reproductive health and childbearing. The Finnish survey covered attitudes and expectations towards family formation and family policies. The questionnaires in St Petersburg and Estonia were similar, having been constructed by the researchers of the REFER project (Reproductive Health and Fertility Patterns in Russia - a comparative approach), while many of the questions used were taken from the Finnish survey (Kesseli et al. 2005). The Russian and Estonian questionnaires were constructed as a joint effort but were administered in the Russian and Estonian languages in the respective countries.

We restricted our study to female respondents aged 18-44 years who were not pregnant at the time of the survey and who had no children, as the population impact on postponing birth depends on the size of the childless population.

\section{Measures}

All women were asked about their childbearing intentions with the question "Are you planning to have a child/children in the future?" The response alternatives were: "1) No, 2) I am not sure (In Estonia "I do not know, I have not decided"), and 3) Yes, I have plans to have a child/children (In Estonia "Yes, I wish to have ...children"), and 4) I am pregnant". (Of these, option 4 was not relevant in this study, as we omitted women who were pregnant at the time of the survey.)

The reasons to postpone having children were asked in St Petersburg with the question "If you do not have a child, what is the reason?", in Estonia "If you do not have a child, why have not you had one?". In Finland the reasons to postpone childbearing were asked with the question "If you want to have a child/children in the future or are not sure about childbearing, what are the reasons for postponing childbearing?". Respondents in all three surveys were then asked to indicate the importance of more than twenty reasons for postponing childbearing. In the St Petersburg and Estonian survey, respondents could choose several alternatives and had to mark only those reasons they felt were important to them; in the Finnish survey respondents indicated the importance of each reason with a 5-point scale (very important - not at all important). This was classified into two categories (important - not important, the latter group including also the 'neither important nor unimportant' option). Out of these reasons we chose seven of the most commonly mentioned reasons: no suitable partner, not mature enough, getting an education first, having a career first, having a stable job first, unsuitable house, unsuitable economic situation. Although these reasons were not mentioned equally often in these three surveys, they all were the most common reasons. 


\section{Independent variables}

Since the information about current partnership status was not comparable across the three surveys, we used an indicator of partnership history instead. In St Petersburg couple relationships were identified with the question "How many marriages or cohabiting relationships have you had?"; in Estonia with "How many times have you been married/cohabiting?"; in Finland with "How many times have you lived in a consensual union or been married?". Those who had been married or cohabited at least once were classified as women with at least one marriage/period of cohabiting. The proportion of never married/cohabiting in all age groups was highest in Estonia and lowest in Finland, St Petersburg falling in between. Appendix Table 1 shows the distributions of sociodemographic background variables in our sample.

Educational level was identified through years of education in St Petersburg and Estonia. In Finland, the respondents indicated their educational attainment level, which was then translated into years (less than 11, 11-13 years, 14-16 years, more than 16 years). The proportion of women with the highest level of education was highest in $\mathrm{St}$ Petersburg and lowest in Finland. Employment was asked in St Petersburg and Finland with the question "What is your current economic activity?" In Estonia women were asked "Are you currently...?" and respondents could choose their current primary status from a list of alternatives. In St Petersburg and Estonia the list included employed, unemployed, housewife/at home, student, retired and other. Self-employed women did not have a separate category but they are included in the employed-category. In Finland the alternatives were full-time wage earner, part-time wage earner, self-employed in agriculture or working on the family farm, other self-employed person (first four options were categorized as "employed"), unemployed, student, housewife, and retired.

In all study areas most women in the age group 18-24 years were employed or students. In St Petersburg the proportion of employed women was higher than in Finland in the age group 18-24 years and in Estonia there were less employed women than in Finland in the age group 25-34 years. In Estonia the proportion of students dropped from $74 \%$ in the age group $18-25$ years to $22 \%$ in the age group $25-34$ years, and in Finland from $55 \%$ to $14 \%$ in the respective age groups. In St Petersburg there were fewer students and in Estonia more students in the age group 18-24 and 25-34 years than in Finland.

\section{Statistical analysis}

We first describe both childbearing intentions and reasons for delaying childbearing by cross-tabulation, testing country-level differences with the t-test. We then used logistic regression analysis adjusting for age, couple relationship, education, and employment to investigate the effect of study area (St Petersburg, Estonia, Finland) on the reason to postpone childbearing. We used Finland as a reference country as there were more changes in economic and social policies in Russia and Estonia in the last two decades, 
which can influence childbearing intentions, than in Finland. Analyses were done by age-groups as the reasons of birth postponement vary markedly by age. Adjusted odds ratios and $95 \%$ confidence intervals were calculated. All analyses were conducted with PASW Statistics version 18.0 (SPSS Inc.).

\section{Results}

\section{How many plan to have children?}

Among women aged 18-24, the proportions of respondents without children in the three areas were similar: 78\% in Finland and St Petersburg and 79\% in Estonia. Among those aged 25-34, women without children constituted 33\% in St Petersburg and 27\% in Estonia, which was significantly lower than in Finland where it was $42 \%$. As the majority of women in all three areas have had their first child by age 35, the proportion of women who were still childless in the oldest age group (35-44 years) was low: 14\% in Finland, 7\% in Estonia, and 8\% in St Petersburg.

Among women without children, plans to have children diminished with increasing age in the three study areas (Table 1). Most women in the age group 18-24 years planned to have children, the proportions in St Petersburg and Estonia were higher than in Finland. In the age group 25-34 years in St Petersburg and Estonia most women planned to have children in the future, while in Finland only half of women considered childbearing. In these two age groups, the proportion of women who did not plan to have any children was low, varying from 1.4 to $7.6 \%$. Thus voluntary childlessness appears to be relatively rare among young women, particularly in St Petersburg and Estonia. In Finland, the proportion of women who were uncertain about future childbearing was also notably higher than in the other two areas.

In the age group 35-44 years, the majority of the childless women did not plan to have children or were uncertain of childbearing. The highest proportion of childless women who had no childbearing plans was found in Finland, followed by St Petersburg and Estonia, although the differences did not reach statistical significance.

\section{Reasons for postponing childbearing}

We next study the reasons for postponing childbearing provided by the respondents themselves. Table 2 shows the proportion of respondents who considered a specific reason to be important, by age group and area. In the youngest group aged 18-24 years, finishing education (partner or self) was among the three most frequently stated reasons for not having had children yet and this was true for all three areas. This was plausible as a clear majority of young women in our sample were still enrolled in education in Estonia and Finland. Somewhat surprising was that also young women in St Petersburg wanted to postpone childbearing due to education, although most women in this age group were employed. Probably they were still searching for better job opportunities which would require additional education. 
Table 1. Childbearing intentions of women without children ${ }^{1}$ by age group in St Petersburg, Estonia and Finland.

\begin{tabular}{lccccccccc}
\hline & \multicolumn{3}{c}{$18-24$} & \multicolumn{3}{c}{$25-34$} & \multicolumn{3}{c}{$35-44$} \\
\hline No plans to & StP & $\mathrm{E}$ & $\mathrm{F}$ & StP & $\mathrm{E}$ & $\mathrm{F}$ & StP & $\mathrm{E}$ & $\mathrm{F}$ \\
have children & 1.8 & $1.4^{*}$ & 4.9 & 6.4 & $2.3^{*}$ & 7.6 & 35.0 & 30.6 & 50.0 \\
Not sure & $9.3^{* * *}$ & $7.8^{* * *}$ & 24.6 & $13.8^{* * *}$ & $13.0^{* * *}$ & 41.7 & 52.5 & 36.7 & 35.2 \\
Yes, I plan to & $87.6^{* * *}$ & $89.9^{* * *}$ & 70.5 & $78.9^{* * *}$ & $84.2^{* * *}$ & 50.7 & 12.5 & 28.6 & 14.8 \\
have children & 1.3 & 0.9 & 0 & 0.9 & 0.5 & 0 & 0 & 4.1 & 0 \\
Missing & 227 & 796 & 183 & 109 & 184 & 132 & 40 & 49 & 54 \\
N & 100 & 100 & 100 & 100 & 100 & 100 & 100 & 100 & 100 \\
Total & & & & & & & & &
\end{tabular}

${ }^{1}$ women who were pregnant were excluded

$\mathrm{StP}=\mathrm{St}$ Petersburg, $\mathrm{E}=$ Estonia, $\mathrm{F}=$ Finland

${ }^{*} p<0.05 ;{ }^{* *} p<0.01 ;{ }^{* * *} p<0.001$ comparing same age-groups in St Petersburg and Estonia to Finland

Both in St Petersburg and Estonia, and somewhat less in Finland "not having a suitable partner", or self/partner being too immature to become a parent, proved to be important reasons for delaying parenthood. Lack of a partner was clearly a hindrance to parenthood among young Estonian and Russian women, among whom it was also less common to live in a union than among young Finns. This may reflect differences in family formation patterns between these areas: in Finland it is relatively common to live in a union but postpone parenthood for several years, whereas in Russia and in Estonia the link between union formation and entry into parenthood is still very strong.

Table 2. Reasons for postponing birth ${ }^{1}$ in St Petersburg, Estonia and Finland, \% of women without children².

\begin{tabular}{|c|c|c|c|c|c|c|c|c|c|}
\hline & \multicolumn{3}{|c|}{$18-24$} & \multicolumn{3}{|c|}{$25-34$} & \multicolumn{3}{|c|}{$35-44$} \\
\hline & StP & $\mathrm{E}$ & $\mathrm{F}$ & StP & $\mathrm{E}$ & $\mathrm{F}$ & StP & $\mathrm{E}$ & $\mathrm{F}$ \\
\hline I have not met a suitable partner & 42.7 & 69.6 & 41.0 & 41.3 & 51.6 & 27.3 & 47.5 & 51.0 & 42.6 \\
\hline Myself/partner immature & 44.5 & 51.9 & 56.8 & 44.0 & 34.2 & 30.3 & 32.5 & 6.1 & 7.5 \\
\hline My/partner education first & 56.4 & 77.8 & 54.9 & 56.4 & 34.8 & 13.6 & 10.0 & 24.5 & 1.9 \\
\hline Career & 17.2 & 31.9 & 35.0 & 19.3 & 22.3 & 28.8 & 12.5 & 4.1 & 13.2 \\
\hline Uncertainty of my/partner job & 33.0 & 60.1 & 17.4 & 29.4 & 14.7 & 12.9 & 5.0 & 10.2 & 1.9 \\
\hline Not suitable house & 34.4 & 55.7 & 29.3 & 30.3 & 26.1 & 25.8 & 12.5 & 8.2 & 9.3 \\
\hline Economic situation & 37.0 & 44.3 & 51.4 & 34.9 & 38.6 & 31.8 & 37.5 & 26.5 & 20.4 \\
\hline $\mathrm{N}$ & 227 & 796 & 183 & 109 & 184 & 132 & 40 & 49 & 54 \\
\hline
\end{tabular}


Uncertainty of work or economic situation was mentioned as the third most important reason to postpone childbearing among the youngest age group in Estonia and in Finland (Table 2). Somewhat surprisingly, in St Petersburg the economic situation was not among the most important reasons for delaying parenthood among young women, but still one-third of young women chose this reason. This probably relates to the fact that in St Petersburg half of women aged 18-24 years were already employed, compared to around one-third of young women in the other two areas.

In the age group 25-34 years, education (of partner or self) was the most important reason to postpone childbearing in St Petersburg, followed by immaturity and no partner (Table 2). In Estonia, half of the women chose the lack of a suitable partner as an important reason. Other reasons were relatively evenly chosen, besides the uncertainty of a job, which was chosen only by $15 \%$ of Estonian women. Among 25-34-yearold women in St Petersburg, uncertainty of job was chosen as an important reason to postpone childbearing more often than among Estonian or Finnish women. In Finland, various reasons were chosen, but none was prominent. Lack of a suitable partner was a much less important reason to postpone parenthood among Finnish women aged 25-34 years than among women in St Petersburg or Estonia.

In Finland, career advancement was clearly a more important reason to postpone childbearing among women aged 18-34 years than among women of the same age in St Petersburg or Estonia.

Since a majority of women had their first child by age 35 , childless women aged $35-44$ years were a selected group and many women aged 35-44 years did not have plans to have children at all. Among those who did still plan to have a child, or were uncertain, the most common reason was having no suitable partner in all the three study areas, other reasons being clearly less important. In St Petersburg, economic situation and immaturity were the other common reasons; in Estonia it was enrollment in education and in Finland economic situation and wanting to advance a career.

\section{Logistic regression results}

Next, we investigate country-level differences in the reasons related to economic or employment by logistic regression analysis, adjusting for age, marital history, education and employment (Table 3), with Finland used as a reference category. The results are focused on economic and employment related reasons, due to their policy relevance as regards the social and economic changes in the two post-Soviet areas.

When examining the impact of the area in the three age groups separately, we found that in the age group of 18-24 years, the impact of unfinished education remained more prominent among Estonians than among women in St Petersburg or in Finland, even after controlling for the level of education and employment (Table 3). 


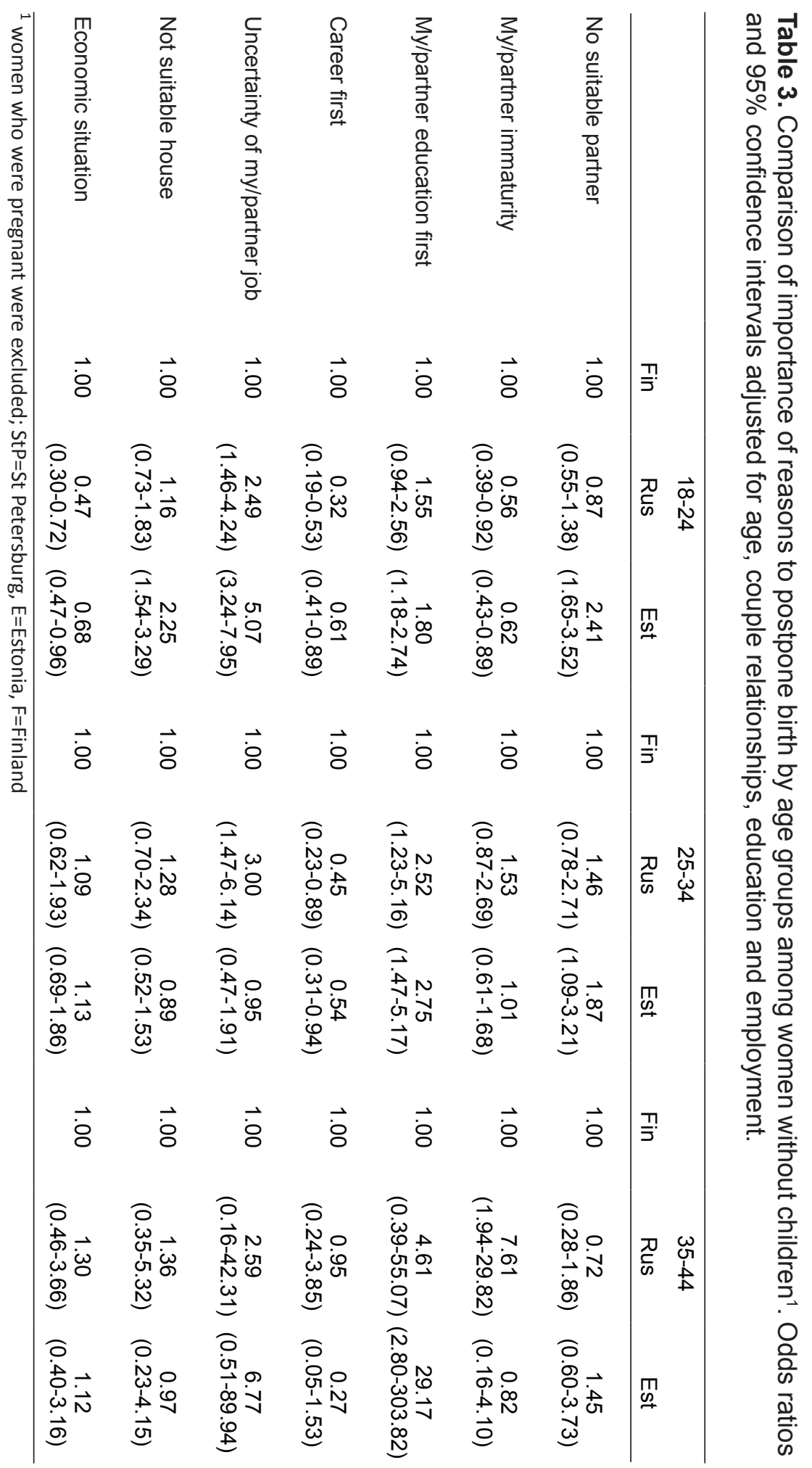


Uncertainty of own or partner's job was more important among women in St Petersburg and in Estonia than in Finland, whereas economic situation appeared to be less important in these two post-Soviet areas than among young Finnish women. In Estonia women were twice more likely to postpone first birth because of "no suitable house" than Finnish women in the youngest age group. For young Estonian women, or women in St Petersburg, postponement of parenthood for career reasons was not as important as for Finnish women.

In the age group 25-34 years, women in Estonia and St Petersburg were again more likely than Finns to postpone childbearing because of education (Table 3). In this age group, only uncertainty of job proved to be more important among Russian women when compared to women in Finland, whereas other reasons were related to poor financial situation. Housing and economic situation were not significantly more important among Russian or Estonian women when compared to Finnish women. Again, career advancement was more important for Finnish women than for Estonian or St Petersburg women.

In the age group 35-44, due to the small sample sizes, the effect sizes and confidence intervals were wide and thus the results are less reliable. Only the impact of enrollment in education appeared to vary between areas: In this age group, Estonian women were more likely to postpone childbearing due to unfinished education when compared to Finnish women (Table 3).

\section{Discussion}

This study provides information on the childbearing intentions of women without children and the importance of reasons to postpone childbearing in the three neighbouring areas, St Petersburg, Estonia and Finland, which share some cultural similarities but otherwise have experienced very different sociopolitical and fertility developments during the last two decades.

The population impact of postponing births depends on the size of the childless population as well as the aims among this population. In all three areas, a clear majority of childless women aged 18-24 and 25-34 years planned to have children. Voluntary childlessness or the proportion of persons not planning to have any children was relatively rare, varying from 1 to 6 percent among Russian and Estonian women, and from 5 to 8 percent among Finnish women in this age group. Compared to the other two areas, Finland has a large number of women aged 35-44 years without children who were not planning to have one, which may impact the demographic situation. Were these childless women to have one child, they could have an impact on overall fertility rates.

In all three study areas, postponement of parenthood among women aged 18-24 years was similarly related to unfinished education. The proportion of students in this age 
group was high, varying from 37 percent in St Petersburg to 73 percent in Estonia. This reflects similarities in attitudes towards having a high education and a better job, as well as increasing individualism and spread of modern family forms, such as cohabitation and disconnection of childbirth from marriage (Klesment 2010).

The average age of completion of education is considerably lower in Estonia and Russia than in Finland. However, young Russian women and men are increasingly continuing their studies while employed so as to improve their chances of finding a better job. A degree in tertiary education is obtained at early age and many consider it insufficient, while distant learning provides possibilities to continue in education while being employed. In Estonia, higher education is probably expected to give more opportunities of finding a job in the demanding European job market. In Finland, on the other hand, education had a less marked impact on postponement. This may be due to a more flexible educational system (allowing for interrupted studies after childbirth, flexibility in the curriculum, ability to combine employment and studies) and economic support given to students, making student status more compatible with parenthood than in the neighbouring countries.

Besides education, economic conditions appeared to be less important for young women in St Petersburg whereas for Estonians, uncertainty of job and housing problems were important reasons for delaying parenthood. On the other hand, career advancement was less important for young women in these two post-Soviet areas as compared with young women in Finland. Temporary employment is very frequent among young women entering the labour market in Finland. It may be that better educated women, in particular, want to secure their foothold in the labour market and a good career and thus postpone parenthood. In St Petersburg, on the other hand, less emphasis on a career might relate to the norm that has persisted to some extent since Soviet times for universal motherhood, where every woman has to have at least one child (relatively early) irrespective of career plans.

Surprisingly, unsuitable housing was perceived to be an important reason only among women in Estonia, but not in St Petersburg. In St Petersburg this may reflect the situation that many young people stay with their parents even after reaching the age of maturity. It may be also possible, albeit to a lesser extent, that some young working couples in St Petersburg could rent apartments or parents helped them financially. In Estonia, this is probably not the case and women seek more independence, which may relate to the importance of living in one's own house/flat. In Finland the family formation phase of young adults implies forming a household of one's own, which includes home-ownership, or living in a rented apartment. Since many young Finns are able to move out from their parents already at a relatively young age, housing conditions may have less importance in the postponement of parenthood. 
Childless women in the age group 25-34 years varied from $20 \%$ to $42 \%$ of samples in each country. They represent women who are among those most willing to start childbearing, although their biological fecundity is decreasing. Thus the reasons provided for delaying childbearing in this age group are particularly relevant for family policy considerations. One of the surprising findings was the effect of education in St Petersburg and Estonia. In St Petersburg the proportion of women who postpone childbearing because of education was highest, and the importance of this reason remained after controlling for other factors in the logistic regression. Even though the proportion of students in this age group in St Petersburg was lower than in the other two areas, many young working women in St Petersburg search for a possibility to continue education or are in distance learning while simultaneously being employed. In Russia in general it is common to finish a university education already at the age of 23-25 years. Being a student after that age is usually associated with personal economic instability and circumstances that are not suitable for childbearing.

In Estonia only one third of the women aged 25-34 mentioned education as a reason for postponing birth. However, in the adjusted analysis this reason appeared to be one of the most important in this age group. Maybe being in continuous education in Estonia gives more independence, advantages and security when competing in a demanding job market. Our finding indicate, however, that the negative impact of continued education may exceed beyond the time it takes to obtain a degree from higher education. Even though finalizing a degree takes longer in Finland (up to 7-10 years) than in the other two study areas, being a student in Finland is more economically secure and the student status is not incompatible with parenthood.

In St Petersburg, the uncertainty of job for the respondent or her partner was a prominent explanation for postponing childbearing. This may reflect the fact that unemployment benefit in St Petersburg is insufficient to provide a living standard for educated women, whose proportion is substantial among all women. In this age group, again, career advancement was more important for Finnish women than for women from St Petersburg or Estonia.

Women aged 35-44 years without children form a very specific group. Many of them are better educated but never found a partner, reflected in that in all three areas the lack of a suitable partner was declared to be a key reason for childlessness. Thus, their childlessness is not so much a birth postponement but rather a result of previous life decisions. In this age group, the proportion of childless women still planning to have children was low in all study areas. However, in Estonia the proportion of women still planning children was highest in this age range. This might relate to the policies introduced in the early 2000s aimed at creating equal opportunities and precluding obstacles in limiting childbearing in Estonia (Estonian human development report 2001, 2002), or to raised expectations towards the techniques of assisted reproduc- 
tion. It is probably also a consequence of the low fertility rates during the 1990s, when many young people postponed first birth, and are now, as things are getting better, reconsidering having a child.

By comparing childbearing intentions between women in two post-Soviet countries and women in an affluent welfare society it is possible to increase our understanding of the differential mechanisms linked to delaying childbearing. Among the strengths of this study is the comparability of the research instrument. Due to the similarity of the surveys and questionnaires we were able to study the postponement of childbearing and their relative importance across three different areas.

However, there are also some limitations to the study. All surveys are cross-sectional and any causality in the relationships cannot be proved. In addition, our study concerned self-rated reasons for postponement of parenthood among childless adult women. Thus, we cannot determine whether these reasons were important or absent among those women who already had children. In all surveys there is quite a large number of non-respondents. The proportions of childless women and reasons for not having children may have been different among them and vary from one country to another. We must also remember that St Petersburg does not represent the whole of Russia and the reasons for postponing childbearing and the importance of reasons of birth postponement probably differ in other parts of Russia. In addition, St Petersburg respondents were from an urban area while the sample drawn in Estonia and Finland included also rural populations.

\section{Conclusion}

Our comparison of three Baltic Sea areas revealed both similarities and differences in the reasons provided for postponement of parenthood and the magnitude of their effects. Prolonged education appeared to be among the most prominent reason for postponement among women aged below 35 years in all three areas. Although the impact of unfinished education on delaying parenthood is already well established, our findings suggest that prolonged education may have different meanings in different societies, pointing towards differences in educational systems. Interestingly, postponement of parenthood due to unfinished education appeared to be more important for women in St Petersburg and Estonia than for Finnish women.

An insecure economic and employment situation, reflected in the importance given to prolonged education and job insecurity as motivations for parenthood postponement in the two post-Soviet areas, suggests that governments could improve fertility by providing family policy measures which clearly focus at young couples, such as flexibility in day care arrangements for those in education and at work, or monetary support to young student mothers. Additionally, in Estonia it may be important to address housing problems. In Finland, on the other hand, policies which support reconciliation of 
family and a career as well as policies which aim to increase permanent employment could promote parenthood among well-educated women in particular.

\section{Acknowledgements}

The study was financially supported by the Academy of Finland (208180, 208186), the Russia in Flux programme (208180 and 208186) and the Baltic Sea Task Force (PH030). The survey in Estonia was financially supported by the Estonian Science Foundation (5456), the Academy of Finland, the Estonian Ministry of Education and Science (SF0182641s04 and SF940026s07) and the Baltic Sea Task Force. The survey in Finland was supported by the Alli Paasikivi foundation.

\section{Appendix 1}

Table 1. Background characteristics of women without children by age group in St Petersburg, Estonia and Finland.

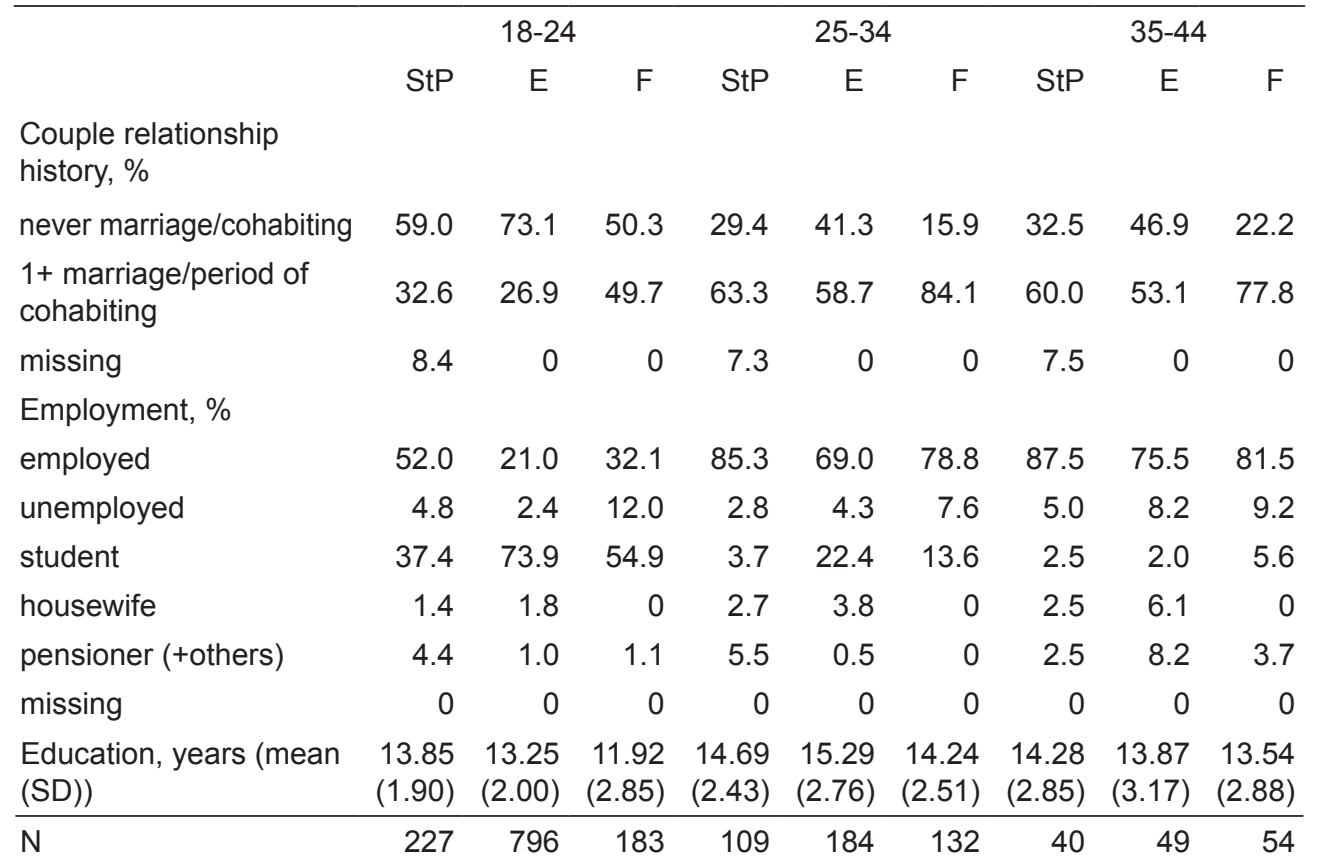




\section{References}

Chistyakova, Natalia. 2004. Citizens of north capital [in Russian]. Demoscope Weekly 1-15, August 2004, vol. 163. Available from: http://demoscope.ru/weekly/2004/0163/ analit02.php

Cooke, Alison, Tracey A Mills and Tina Lavender. 2010. Informed and uninformed decision making-women's reasoning, experiences and perceptions with regard to advanced maternal age and delayed childbearing: a meta-synthesis. International Journal of Nursing Studies 47(10): 1317-29.

Decree No. 485 (2003) On the list of social indications for induced termination of pregnancy.

Elizarov, Valeriy. 2002. Economic support of families in Russia [in Russian]. Demoscope Weekly, vol. 51-52. Available from: http://demoscope.ru/weekly/2002/051/polit03. php.

Estonian Birth Medical Registry. 2009. Available from: http://www.tai.ee/en/r-and-d/ registers/estonian-medical-birth-registry-and-estonian-abortion-registry

Estonian human development report. 2001. Available from: http://lin2.tlu.ee/ teap/ nhdr/2001/en/2.1.html

Estonian human development report. 2002. Available from: http://lin2.tlu.ee/ teap/ nhdr/2002/PDF/EIA\%202002\%20i-ch3.pdf

Estonian human development report. 2008. Available from: http://www.kogu.ee/public/ EIA2008 eng.pdf

European health for all database (HFA-DB). 2012. Available from: http://data.euro. who.int/hfadb/

Frejka, Tomas and Jean-Paul Sardon. 2006. First birth trends in developed countries: Persisting parenthood postponement. Demographic Research 15(6), 147-80.

Frejka, Tomas, Tomáš Sobotka, Jan M Hoem and Laurent Toulemon. 2008. Summary and general conclusions: childbearing trends and policies in Europe. Demographic Research. 01 July 2008, Vol. 19: 5-14.

Forssén, Katja. 2000. Lapsiperheet ja hyvinvointivaltio. Katsaus suomalaisen perhepolitiikan kehitykseen. In: Ritakallio VM, Ervasti H, Forssén K, Nurmi K (eds), Eriarvoisuutta paikantamassa. Sosiaalipoliittisen yhdistyksen tutkimuksia 55. Turku: Painosalama.

Goldstein, Joshua, Wolfgang Lutz and Maria Rita Testa. 2003. The emergence of subreplacement family size ideals in Europe. Population Research and Policy Review 22(5-6): 479-96.

Heck Katherine E, Kenneth C Schoendorf, Stephanie J Ventura and Johan L Kiely. 1997. Delayed childbearing by education level in the United States, 1969-1994. Maternal and Child Health Journal 1: 8-18.

Karro, Helle. 1997. Abortion in the framework of family planning in Estonia. Acta Obstetricia Gynecologica Scandinavica Supplement 164: 46-50.

Kesseli Katija, Elena Regushevskaya, Tatiana Doubikaytis, Svetlana Kirichenko, Anna Rotkirch, Elina Haavio Mannila, Olga Kuznetsova and Elina Hemminki. 2005. Reproductive health and fertility in St Petersburg. Report on a survey of 18-44 
Klesment, Martin. 2010. Fertility development in Estonia during the second half of the $X X$ century and its implications. Analytical Summary. PhD thesis, Tallinn.

Laanpere, Made, Kaja Rahu, Kai Part, Tatiana Dubikaytis and Helle Karro. 2012. Ethnic differences in factors associated with the use of contraception among 20- to 44-year-old women in Estonia and St Petersburg, Russia. Contraception 86: 132-40.

Larsson, Margareta, Gunilla Aneblom, Viveca Odlind and Tanja Tyden. 2003. Reasons for pregnancy termination, contraceptive habits and contraceptive failure an early pregnancy termination. Acta Obstetricia Gynecologica Scandinavica 81: 64-71.

National Institute for Health Development. 2012. [accessed 06 August 2013]. Available from: http://www.tai.ee/images/PDF/Registrid/LK 12.xls

Ovtcharova, Lilia. 2005. The profile of Russia poverty [in Russian]. Demoscope Weekly. May 2005, vol. 89. Available from: http://www.demoscope.ru/acrobat/ps89.pdf

Paajanen, Pirjo. 2005. Eri teitä vanhemmuuteen. Kaksikymppisenä ja kolmekymppisenä lapsen saaneiden näkemyksiä perheellistymisestä ja vanhemmuudesta. Perhebarometri 2005. Helsinki: Väestöliitto Väestöntutkimuslaitoksen Katsauksia E 21/2005.

Part Kai, Made Laanpere, Kaja Rahu, Kai Haldre, Mati Rahu and Helle Karro. 2007. Estonian women's health: sexual and reproductive health, health behavior, attitudes and use of health services. Survey report, Tartu.

Perelli-Harris, Brienna. 2005. The path to lowest-lost fertility in Ukraine. Population Studies 59(1): 55-70.

Rasch Vibeke, Lisbeth B Knudsen and Hanne Wielandt. 2001. Pregnancy planning and acceptance among Danish pregnant women. Acta Obstetricia Gynecologica Scandinavica 80: 1030-5.

Regushevskaya Elena, Tatiana Dubikaytis, Minna Nikula, Olga Kuznetsova and Elina Hemminki. 2008. The socioeconomic characteristics of risky sexual behavior among reproductive-age women in St Petersburg. Scandinavian Journal of Public Health 36: $143-52$.

Regushevskaya Elena, Tatiana Dubikaytis, Made Laanpere, Minna Nikula, Olga Kuznetsova, Elina Haavio-Mannila, Helle Karro and Elina Hemminki. 2009. Risk factors for induced abortions in St Petersburg, Estonia and Finland. Results from survey among reproductive age women. European Journal of Public Health 14(3): $176-86$.

Rotkirch, Anna and Katja Kesseli. 2012. 'Two children puts you in the zone of social misery': Childbearing and risk perception among Russian women. In: H.Carlbäck, Y.Gradskova and Zh. Kravchenko (eds) And they lived happily ever after. Norms and everyday practices of family and parenthood in Russia and Eastern Europe, pp. 145-164. Budapest: Central European University Press.

Anna Rotkirch, Anna Temkina and Elena Zdravomyslova. 2007. Who helps the degraded housewife? Comments on Vladimir Putin's demographic speech. European Journal of Women's Studies 14: 4, 349-357.

Rønsen, Marit. 2004. Fertility and family policy in Norway-a reflection on trends and possible connections. Demographic Research 10: 265-86.

St Petersburg Public Health Committee, official informational server (2010). Statistics. 
[in Russian] [accessed 06 August 2013]. Available from: http://www.zdrav.spb.ru/ Sobotka, Tomas. 2008. Does persistent low fertility threaten the future of European populations? In: Surkyn J, Deboosere P and van Bavel J (eds.) Demographic challenges for the 21 st century. Brussels: VUBPRESS (Brussels University Press), pp. 27-89.

Sobotka, Tomas. 2004. Postponement of childbearing and low fertility in Europe. $\mathrm{PhD}$ Thesis, University of Groningen.

Sobotka, Tomas. 2009. Sub-replacement fertility intentions in Austria. European Journal of Population 25: 387-412.

Sotsiaalministeerium. 2010. [accessed06 August 2013]. Available from: http://euraxess. ee/incoming-researchers/family/family-benefits/birth-parental-benefit/

Statistics Finland. 2012. Births. [accessed 06 August 2013]. Available at: http://www. $\underline{\text { stat.fi }}$

Statistics Finland. 2008. Statistical Yearbook of Finland 2008. Helsinki: Statistics Finland.

Tanturri, Maria L and Letizia Mencarini. 2008. Childless or childfree? Paths to voluntary childlessness in Italy. Population and Development Review 34(1): 51-77.

Testa Maria R. 2007. Childbearing preferences and family issues in Europe: Evidence from the Eurobarometer 2006 survey. Vienna Yearbook of Population Research, $357-79$.

Testa, Maria R. 2011. Family Sizes in Europe Evidence from the 2011 Eurobarometer Survey. European Demographic Research Papers.

UNICEF. 2000. Young People in Changing Societies. UNICEF Regional monitoring report 7.

Zakharov, Sergey. 2002. Is Russian fertility increasing? Population and Society 68.

Zakharov, Sergey. 2008. Russian Federation: from the first to the second demographic transition. Demographic Research 19(24): 907-72. 